\title{
Reproductive biology of the peacock bass Cichla piquiti (Perciformes: Cichlidae), an exotic species in a Neotropical reservoir
}

\author{
Augusto B. C. Vieira, Luiz F. Salvador-Jr., Rafael M. C. Melo, \\ Gilmar B. Santos and Nilo Bazzoli
}

To analyze the reproductive biology of the peacock bass Cichla piquiti, 361 specimens were collected bimonthly in the Itumbiara Reservoir, southeast Brazil, from December 2004 to November 2005. Males and females in reproductive activity occurred during almost the entire year, with reproductive peak occurring before the beginning of the rains when the water temperature remained low, indicating that these environmental variables do not directly influence in the reproduction of $C$. piquiti. The long reproductive period, partially spent ovaries contained postovulatory follicles and oocytes in all developmental stages, indicate asynchronous development of oocytes and multiple spawning. The mean total length and body weigth were, respectively, $38.2 \pm 7 \mathrm{~cm}$ and 965.0 $\pm 654.0 \mathrm{~g}$ for males and $37.4 \pm 6.1 \mathrm{~cm}$ and $899.0 \pm 495.0 \mathrm{~g}$ for females, statistically showing no sexual dimorphism in size. The smallest male and female found in advanced maturation stage measured $31.0 \mathrm{~cm}$ and $29.0 \mathrm{~cm}$ of total length, respectively. The body condition (K) of males and females did not present significant differences during the reproductive cycle and the slope $(b)$ of the length-weight relationship was 3.22, suggesting that reproduction and the annual hydrology cycle do not interfere in the health condition. Cichla piquiti is an exotic piscivore fish that is well adapted to this Neotropical reservoir, which exhibits environmental conditions considerably different from its original habitat. This study indicates that the species presents plasticity in reproduction and in allocation of resources, probably due the aseasonality of the reservoir and the exploitation of native species.

Para analisar a biologia reprodutiva do tucunaré Cichla piquiti foram coletados bimestralmente 361 exemplares no reservatório de Itumbiara, sudeste do Brasil, no período de dezembro/2004 a novembro/2005. Machos e fêmeas em atividade reprodutiva ocorreram durante quase todo ano, com pico reprodutivo antes do início das chuvas, quando a temperatura da água permanecia ainda baixa, indicando que estas variáveis ambientais não influenciaram diretamente na reprodução de C. piquiti. O longo período reprodutivo, ovários parcialmente desovados contendo folículos pós-ovulatórios e ovócitos em todos os estádios de desenvolvimento, indicaram desenvolvimento assincrônico dos ovócitos e desova múltipla. A média de comprimento total e peso corporal foram, respectivamente, 38,2 \pm 7,0 cm e 965,0 \pm 654,0 g para machos e 37,4 \pm 6,1 cm e 899,0 \pm 495,0 g para fêmeas, estatisticamente não mostrando dimorfismo sexual em tamanho. Os menores exemplares, macho e fêmea, capturados no estádio de maturação avançada mediram 31,0 cm e 29,0 cm de comprimento total, respectivamente. O fator de condição (K) de machos e fêmeas não apresentou diferenças significativas durante o ciclo reprodutivo e o coeficiente angular $(b)$ da relação peso-comprimento foi 3,22, sugerindo que a reprodução e o ciclo hidrológico anual não interferem na condição de saúde. Cichla piquiti é um peixe piscívoro exótico que está bem adaptado a este reservatório neotropical, o qual exibe condições ambientais consideravelmente diferentes de seu habitat original. Este estudo indica que a espécie apresenta plasticidade na reprodução e na alocação de recursos, provavelmente devido a não sazonalidade do reservatório e a exploração das espécies nativas.

Key words: Reproduction, Multiple spawning, Body condition, Phenotypic plasticity.

\section{Introduction}

The genus Cichla Bloch \& Schneider, 1801 comprises 15 species, known as peacock basses, originally distributed in the Amazon, Tocantins and Orinoco Rivers basins (Kullander \& Ferreira, 2006). Cichla piquiti Kullander \& Ferreira, a recently described species, is restricted to the Tocantins River basin, but was introduced in the Paraná River basin in Brazil and Paraguay. In reservoirs located along the upper Paraná River basin, the local species was first referred to as Cichla ocellaris Bloch \& Schneider (Santos et al., 1994), because of the morphological resemblance of this species with C. piquiti (Kullander \& Ferreira, 2006).

Species of Cichla are the largest cichlids and the most widespread predators of South America (Winemiller et al., 1997). The large introduction of Cichla into reservoirs and

Programa de Pós-Graduação em Zoologia de Vertebrados, Pontifícia Universidade Católica de Minas Gerais. Av. Dom José Gaspar, 500, Coração Eucarístico, 30.535-610 Belo Horizonte, MG, Brazil. gutobicalho@hotmail.com (ABCV), neotropicalresearch@yahoo.com.br (LFSJR),rmagnocm@yahoo.com.br (RMCM), astyanax@pucminas.br (GBS), bazzoli@pucminas.br (NB) 
natural lakes of tropical and subtropical countries is due to its importance to sport and commercial fishing and to the quality of its meat (Winemiller, 2001; Kullander, 2003). The wide distribution of the peacock bass out of its natural habitat is related to several factors that increase its possibilities of survival, including an opportunistic piscivore alimentary habit (Jepsen et al., 1997), a preference for spawn in lentic environments where food supply for larvae and young is abundant (Zaret, 1980), and the construction of nests and biparental care (Muñoz et al., 2006). The negative impact of these introductions on natural fish communities is well known, where Cichla drastically reduces the abundance and diversity of native species (Zaret \& Paine, 1973; Santos et al., 1994; Latini \& Petrere, 2004; Novaes et al., 2004). In the Itumbiara Reservoir, the present study area, the peacock bass was first registered in 1980, and is now the most abundant piscivore fish (Santos, 1999).

Studies on the biology of Cichla show the reproductive aspects of C. ocellaris (Lowe-McConnell, 1969), Cichla temensis Humboldt, Cichla intermedia Machado-Allison and Cichla orinocensis Humboldt (Jepsen et al., 1997, 1999; Winemiller et al., 1997; Winemiller, 2001) and Cichla monoculus Spix \& Agassiz (Muñoz et al., 2006) in their natural environment. Studies on the reproduction of Cichla introduced into tropical reservoirs have been done on $C$. ocellaris (Zaret, 1980; Magalhães et al., 1996), C. monoculus (Chellappa et al., 2003; Gomiero \& Braga, 2004) and Cichla kelberi Kullander \& Ferreira (Souza et al., 2008). Other studies address ecological aspects of Cichla in native (Hoeinghaus et al., 2006) and exotic environments (Gomiero \& Braga, 2003; Gomiero et al., 2008). Considering the lack of studies about the peacock bass $C$. piquiti, the aim of this work was to analyze the reproductive biology of this exotic species in order to evaluate its adaptation capacity in a Neotropical reservoir.

\section{Material and Methods}

Study area. The Itumbiara Reservoir is part of the Paranaíba River, on the boarder of the States of Minas Gerais and Goiás, in southeast Brazil ( $\left.18^{\circ} 25^{\prime} \mathrm{S} 49^{\circ} 06^{\prime} \mathrm{W}\right)$. It has $814 \mathrm{~km}^{2}$ of flooded area, and is considered a mega reservoir according to the classification of Bernacsek (1984). This reservoir possesses only two main tributaries, the Corumbá and Araguari Rivers, and presents a highly diverse ichthyofauna, with about 50 native species (Santos, 1999). The air temperature in the region varies from $21^{\circ} \mathrm{C}$ to $32^{\circ} \mathrm{C}$, and the annual precipitation is in between 1300-1400 mm with a wet season from September to March (Santos, 1999). The area selected for specimen collection was the intermediate region of the reservoir where ranches dedicated to sport fishing are located. These places represent the main points of landing with caught fish, a fact that facilitated the collection of viscera for later analysis. To avoid bias, specimens were randomly chosen from landing boats. The data of water temperature [minimum and maximum temperature $\left(\mathrm{C}^{\circ}\right)$ ], accumulated rainfall $(\mathrm{mm})$ and level of water (m) of the Itumbiara Reservoir was measured daily by Furnas
Electric Power Plants, Inc. For water temperature and level of water the respective monthly means were grouped bimonthly according to the period sampled.

Sample collection and biological indexes. Six bimonthly campaigns for data collection were made to the Itumbiara Reservoir during December 2004 to November 2005. A total of 361 specimens of $C$. piquiti (182 males and 179 females) were captured and measured (total length $=\mathrm{Lt}$, and total weight $=$ Wt). A voucher specimen (access number MZUSP 40296) was deposited in the Museu de Zoologia of the Universidade de São Paulo. After evisceration, the stomach and liver of each specimen were fixed in $10 \%$ formalin solution for 24 hours and then transferred to $70 \%$ alcohol. Gonad samples of each specimen were fixed in Bouin's fluid for 8 to10 hours and then transferred to $70 \%$ alcohol.

Viscera were dissected to measure the weight of the gonads (Wg), the liver (Wl) and the stomach (Ws). Biometric data were used to determine the following biological indexes: gonadosomatic (GSI $=\mathrm{Wg} / \mathrm{Wt} .100)$, hepatosomatic (HSI = $\mathrm{Wl} / \mathrm{Wt}$. 100), stomach repletion (SRI = Ws / Wt x 100) and Fulton's condition factor $\left(\mathrm{K}=\mathrm{Wt} .100 / \mathrm{Lt}^{3}\right)$.

Reproductive analysis. Gonadal maturation stages were established based on macroscopic and microscopic morphology of the gonads and on the variation of GSI. A total of 361 gonads previously fixed in Bouin's fluid were submitted to routine histological techniques for confirmation of the gonadal maturation stages determined macroscopically (Bazzoli, 2003). The type of spawning was determined through histological analyses of spawned ovaries and the analysis of the frequency of the different gonadal maturation stages.

Data analysis. A G-test of independence was used to compare the number of specimens of each gonadal maturation stage across bimesters for both sexes to determine significant differences between absolute values. The correlation coefficient $\left(r^{2}\right)$ was used to correlate water temperature, accumulated rainfall, and level of water of the reservoir with the mean values of GSI(all variables calculated for bimester). Mean values of the biologic indexes calculated by sex for each gonadal maturation stage were compared using oneway ANOVA followed by Tukey's post hoc test to determine significant differences between mean values. A Chi-square $\left(\chi^{2}\right)$ test was used to assess the significance of differences in the sex ratio of males to females. A Mann-Whitney U-test was used to determine the significance of differences of $\mathrm{Lt}$ and $\mathrm{Wt}$ between males and females.

The length-weight relationship of $C$. piquiti was calculated using the equation $\mathrm{Wt}=a \mathrm{Lt}^{b}$, where $a$ is a coefficient related to body form and $b$ (slope) is an exponent indicating isometric growth when around 3. Parameters $a$ and $b$ of the exponential curve were estimated by linear regression analysis over ln-transformed data, and the degree of association between the $\ln \mathrm{Lt}$ and $\ln \mathrm{Wt}$ was evaluated by the correlation coefficient $\left(\mathrm{r}^{2}\right)$. 


\section{Results}

Reproductive cycle. Based on morphological characteristics of spermatogenic cells and of oocytes, the following gonadal maturation stages were established for males and females of C. piquiti: 1 - resting, 2 - initial maturation, 3 - advanced maturation and 4 - partially spent. In the present study, no totally spent males and females were found. Fishes in reproductive activity occurred throughout the year, except in April to July for males. The peak of $C$. piquiti males and females in initial maturation occurred during June/July (mean water temperature $=24.0^{\circ} \mathrm{C}$, accumulated rainfall $=19.4 \mathrm{~mm}$ ) and of advanced maturation in August/September $\left(25.6^{\circ} \mathrm{C}\right.$, $26.0 \mathrm{~mm}$ ). The peak of partially spent specimens occurred in October/November $\left(29.2^{\circ} \mathrm{C}, 458.0 \mathrm{~mm}\right)$ (Figs. 1 and 2). The long reproductive period, the absence of totally spent females, and the partially spent ovaries which contained postovulatory follicles and oocytes in all developmental stages indicated asynchronous development of the oocytes and multiple spawning for $C$. piquiti.

The correlation coefficient $\left(\mathrm{r}^{2}\right)$ between the mean GSI of $C$. piquiti and the environmental variables of the reservoir during the period from December 2004 to November 2005 for males and females, were respectively: water temperature $=0.08$ and 0.05 (Fig. 2a), accumulated rainfall $=0.16$ and 0.04 (Fig. 2b) and level of water $=0.48$ and 0.39 (Fig. 2c).

Biological indexes. Mean GSI values calculated for males and females accompanied the maturation of the gonads. Advanced maturation males showed significant differences of GSI ( $\mathrm{F}=22.829$, $\mathrm{df}=3$, $\mathrm{p}<0.001$ ) among others stages. Advanced maturation and partially spent females showed significant differences of GSI $(F=69.062$, $d f=3, p<0.001)$ with all other stages. Males did not present significant differences in HSI $(\mathrm{F}=2.558, \mathrm{df}=3, \mathrm{p}=0.056)$ during the reproductive cycle and SRI $(\mathrm{F}=2.761$, $\mathrm{df}=3, \mathrm{p}=0.043$ ) values were significantly different among the resting and advanced maturation stages. For females, $\operatorname{HSI}(\mathrm{F}=4.977, \mathrm{df}=3$, $\mathrm{p}=0.002)$ and SRI $(\mathrm{F}=5.285, \mathrm{df}=3, \mathrm{p}=0.001)$ were significantly lower in the advanced maturation stage. The $\mathrm{K}$ values calculated for males $(\mathrm{F}=1.922, \mathrm{df}=3, \mathrm{p}=0.127)$ and females $(\mathrm{F}=2.046$, df $=3, \mathrm{p}=0.109)$ did not present significant variations throughout the reproductive cycle (Fig. 3).

Population structure and growth relationship. During the study period, 182 males (50.4\%) and 179 females (49.6\%) of C. piquiti were captured, indicating a sex ratio of approximately $1: 1$, showing no significant differences $\left(\chi^{2}=0.012, \mathrm{df}=1, \mathrm{p}>0.05\right)$. The largest specimen captured was a male of $65.0 \mathrm{~cm}(\mathrm{Lt})$ and $3750.0 \mathrm{~g}(\mathrm{Wt})$, and the mean Lt and Wt were $38.2 \pm 7.0 \mathrm{~cm}$ and $965.0 \pm 654.0 \mathrm{~g}$, respectively. Among the females, the largest specimen captured was $57.7 \mathrm{~cm}(\mathrm{Lt})$ and $3250.0 \mathrm{~g}(\mathrm{Wt})$, and the mean $\mathrm{Lt}$ and Wt were $37.4 \pm 6.1 \mathrm{~cm}$ and $899.0 \pm 495.0 \mathrm{~g}$, respectively. Significant differences in the Lt (Mann-Whitney test $=15703.5, \mathrm{p}>0.05)$ and Wt $($ Mann-Whitney test $=16065.5$, $\mathrm{p}>0.05$ ) between males and females were not observed. As
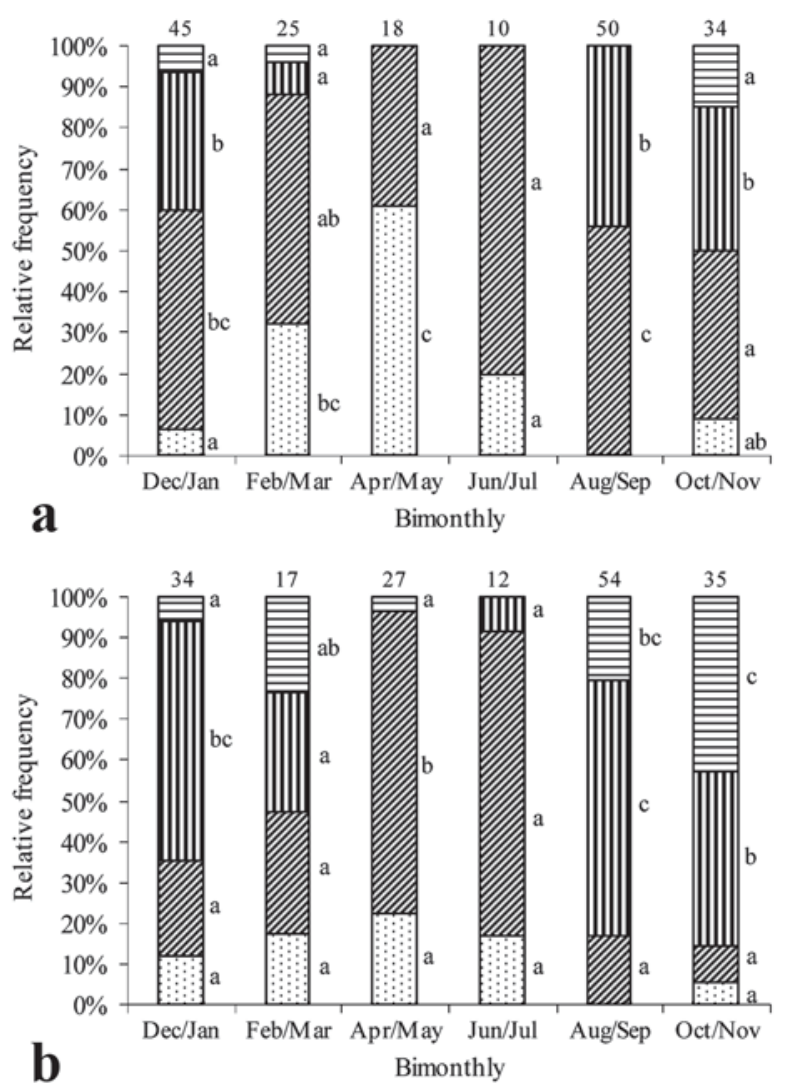

Fig. 1. Relative bimonthly frequency (\%) of gonadal maturation stages for males (a) and females (b) of Cichla piquiti sampled between December 2004 and November 2005 [resting (dotted), initial maturation (oblique lines), advanced maturation (vertical lines), partially spent (horizontal lines)]. Absolute frequencies of each gonadal maturation stage along the bimesters followed by different letters are significantly different (G-test of independence, $\mathrm{p}<0.05)$. Sample size is given above bars.

from $51.0 \mathrm{~cm}$ and $2251.0 \mathrm{~g}$ was observed that all specimens were in reproductive activity (Fig. 4). The smallest male and female found in advanced maturation stage measured $31.0 \mathrm{~cm}$ and $29.0 \mathrm{~cm}(\mathrm{Lt})$, respectively. The length-weight relationship was estimated for the males and females separately. Parameter $b$ was 3.26 for males and 3.18 for females and parameter $a$ was 0.009 for males and 0.012 for females. The correlation coefficient $\left(\mathrm{r}^{2}\right)$ was 0.91 and 0.98 to male and to female, respectively.

\section{Discussion}

In this study, males and females of $C$. piquiti in reproductive activity were observed during almost the entire year, with reproductive peak in August and September, period prior the rainy season and with low temperatures in the region of Itumbiara. In contrast, other exotic Cichla introduced into Neotropical reservoirs presented reproductive peak in the rainy period and with high temperatures (Magalhães et al., 1996; Gomiero \& Braga, 2004; Souza et al., 2008). In native populations of Cichla there is pronounced reproductive 

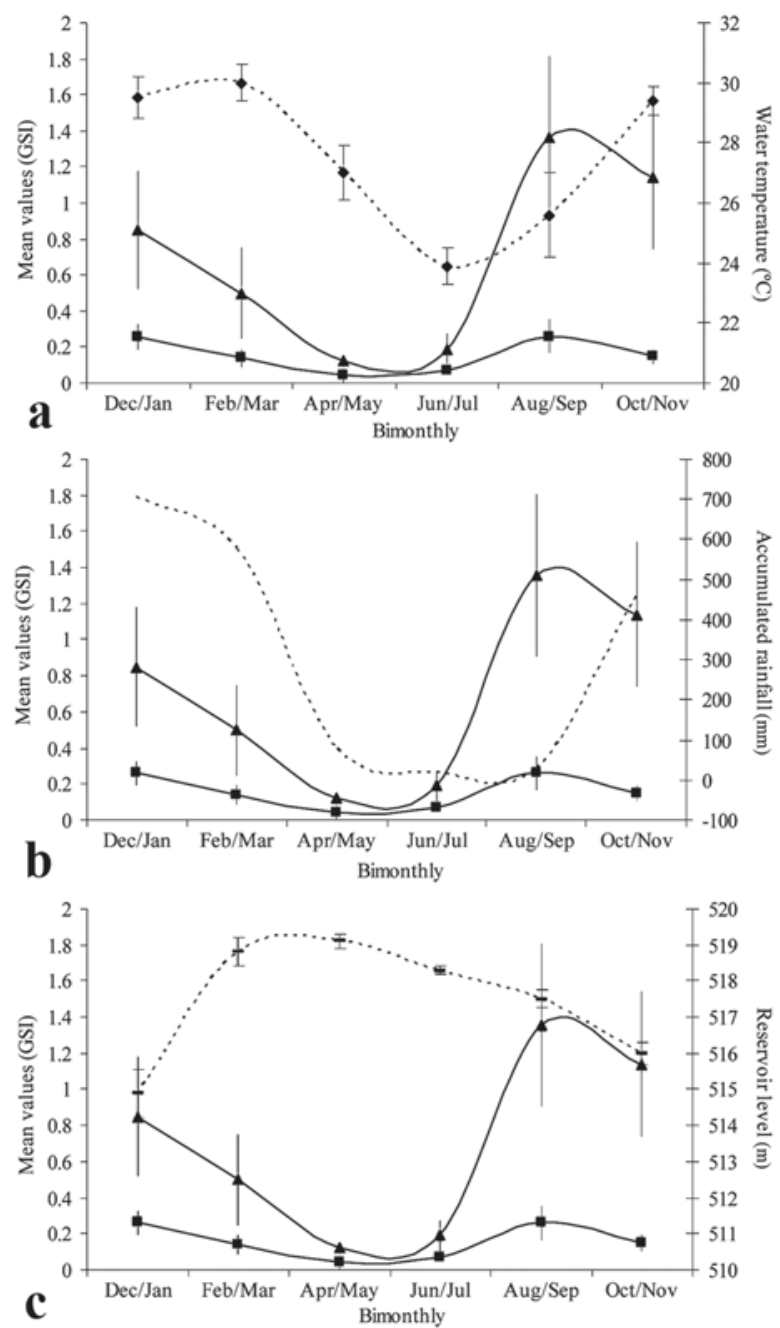

Fig. 2. Male and female gonadosomatic index (GSI) \pm SD of Cichla piquiti and environmental variables \pm SD collected at the Itumbiara Reservoir between December 2004 and November 2005 [GSI male (square), GSI female (triangle); (a) water temperature, (b) accumulated rainfall, (c) reservoir level].

seasonality, with increased activity of nesting and breeding at the beginning of the rainy season (Lowe-McConnell, 1969; Jepsen et al., 1997, 1999; Winemiller et al., 1997; Muñoz et al., 2006). The low correlation between GSI and the rains, the water temperature and the level of water of the Itumbiara Reservoir suggests that these variables do not directly influence the reproduction of $C$. piquiti. In contrast, the significant seasonal fluctuation in the level of water in Amazonian rivers influences the selection of sites for spawning and access to food resources of the floodplain in Cichla (LoweMcConnell, 1979; Jepsen et al., 1997; Muñoz et al., 2006).

Various criteria have been used to determine the type of spawning for teleost fish. Cichla piquiti was classified as multiple spawn, based on previously established criteria such as asynchronous development of the oocytes, release of the oocytes in batches, long spawning period, high frequency of females presenting partially spawned ovaries and slow and
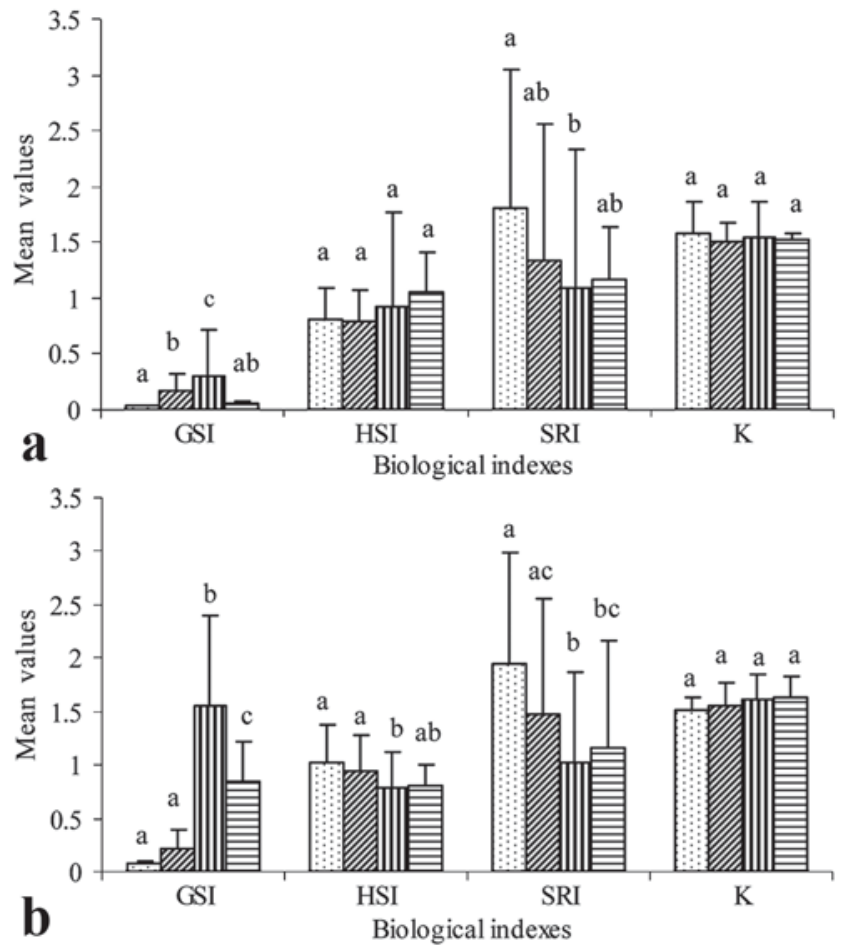

Fig. 3. Mean values \pm SD of the gonadosomatic (GSI), hepatosomatic (HSI), stomach repletion (SRI) and condition factor $(\mathrm{K})$ indexes according to gonadal maturation stages of males (a) and females (b) of Cichla piquiti sampled during the period from December 2004 to November 2005 [resting (dotted), initial maturation (oblique lines), advanced maturation (vertical lines), partially spent (horizontal lines)]. Values followed by different letters above the bars of each index are significantly different (one-way ANOVA, $\mathrm{p}<0.05$ ).

gradual reduction of gonads size as expressed by the GSI (Bazzoli, 2003). The type of spawning of Cichla presents variations depending on habitat type. In natural conditions, the energetic cost of reproduction and defense of the offspring of Cichla that live under strong seasonal hydrology in floodplains of South American rivers, probably conditions most individuals to spawn only once per year (Jepsen et al., 1999). Similarly, Lowe-McConnell (1979) observed that fluctuations in the availability of resources in a seasonal habitat can induce reproductive seasonality in Cichlidae. Regarding Cichla introduced into tropical reservoirs, there is consensus that spawning is multiple (Zaret, 1980; Magalhães et al., 1996; Chellappa et al., 2003; Souza et al., 2008; present study), indicating that Cichla living under more stable hydrological conditions, such as reservoirs, are energetically capable of multiple spawning annually. This type of spawning in Cichla has been related to the release of different batches of oocytes at different times allowing the larvae to develop and overtake the zooplanktophagous stage after they use a different niche, thus reducing competition for the same food resource among different sets of larvae (Zaret, 1980; Jepsen et al., 1997).

During the reproductive cycle, the mean HSI of C. piquiti 

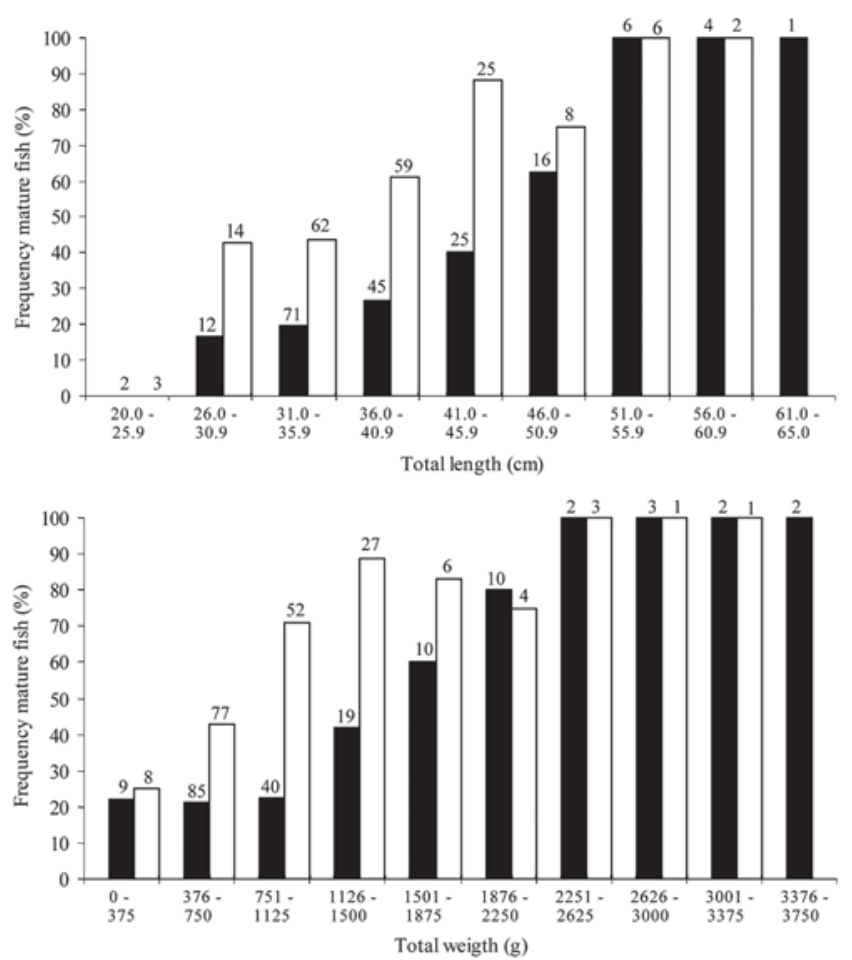

Fig. 4. Percentage of sexually mature males (solid bar) and females (empty bar) of Cichla piquiti collected during the period from December 2004 to November 2005. Sample size is given above bars.

females presented values significantly lower in the advanced maturation stage, indicating the transfer of hepatic substances to the ovaries during the vitellogenesis (Selman \& Wallace, 1989). The SRI of females present values significantly lower during the advanced maturation stage, indicating that $C$. piquiti females reduce feeding activities during the reproductive period. In fact, Cichla usually do not feed during the breeding period (Jepsen et al., 1997, 1999) and the guarding phase (Zaret, 1980; Muñoz et al., 2006). Significantly higher values of SRI were observed in males and females of $C$. piquiti in the resting stage, probably for accumulation of energetic reserves for the development of the gonads. In a Venezuelan blackwater river, Cichla presented full stomachs during the rains, while in the dry season, period of preparation for spawning, the feeding frequency and body condition of the species declined (Jepsen et al., 1997, 1999). In contrast, in C. piquiti the body condition $(\mathrm{K})$ of males and females did not present significant variations during the reproductive cycle, suggesting that the reproductive activities do not interfere in the health condition of $C$. piquiti. The pattern of feeding and body condition of Cichla in native habitats showed significant variation among seasons, due to the seasonality in the density of prey and in the reproduction of these species (Jepsen et al., 1997, 1999; Hoeinghaus et al., 2006). This pattern was not observed for C. piquiti, probably due the wide availability of non-seasonal native prey in the Itumbiara Reservoir.

A sex ratio of $1: 1$, characteristic of tropical fish, was observed for C. piquiti. Chellappa et al. (2003) reported a sex ratio of approximately 1:1 for $C$. monoculus, with a small predominance of females. In native populations of Cichla, Jepsen et al. (1997) observed that males were almost twice more numerous than females. This ratio varies considerably among species, but in most of the cases it is around 1:1, varying from year to year in the same population (Vazzoler, 1996). The sexual dimorphism in size between males and females in Cichla has been documented in native populations (Lowe-McConnell, 1969; Muñoz et al., 2006) and in exotic populations (Zaret, 1980; Chellappa et al., 2003). Apparently males of $C$. piquiti are larger and heavier than females, but statistical analysis did not find significant differences in the Lt and Wtbetween the sexes. In native habitat, males and females of $C$. temensis and $C$. intermedia also had similar body lengths and showed no sexual dimorphism in size, in contrast to C. orinocensis (Jepsen et al., 1999). The fact that females convert food resources in the production of eggs is reflected in the size of first sexual maturation for Cichla, where the males are often larger than females (Zaret, 1980; Winemiller et al., 1997; Chellappa et al., 2003). This pattern is corroborated by the size of first maturation of $C$. piquiti, with males and females measuring $31.0 \mathrm{~cm}$ and $29.0 \mathrm{~cm}(\mathrm{Lt})$, respectively. The slope $(b)$ value is a measure of individual fitness, wich includes the reproductive potential, the ability to escape predators, and the ability to swim and pursue prey (Zaret, 1980). In the length-weight relationship of C. piquiti the slope value was 3.22, characterizing an increment of Wt greater than the increment of Lt for both sexes. For different species of Cichla in Amazonian rivers the growth was negative allometric $(b<3)$ (Zaret, 1980; Jepsen et al., 1999). Zaret (1980) observed that Cichla introduced in a new habitat can show slope values significantly higher than those shown in native waters, due mainly to the exploitation of native fishes. This growth rate may decrease significantly some years after the introduction, as observed in C. ocellaris after 10 years of its introduction into the Gatun Lake (Zaret, 1980), or remain high as observed in C. piquiti, after 25 years of its introduction into the Itumbiara Reservoir.

Knowledge of the reproductive biology of an exotic species is important in order to evaluate its spread into a new habitat, being the basic stage in analyzing the impacts on native ichthyofauna. In contrast with Cichla in native habitats, C. piquiti introduced in the Itumbiara Reservoir shows reproductive activity during almost the entire year, with reproductive peak prior to the beginning of rains, when the water temperature is still low. Moreover, the body condition of $C$. piquiti varies little throughout the year, and the fitness observed in the length-weight relationship is high, probably due to the exploitation of native species. These findings showed that $C$. piquiti presents great reproductive plasticity, being well adapted to this Neotropical reservoir, which exhibits environmental conditions considerably different from its original habitat. The reproductive success and proliferation of peacock basses outside of its natural habitat, mainly in lentic waters, confirms the marked phenotypic plasticity of Cichla in the allocation of resources for growth and 
reproduction, and displays a reproductive pattern adaptive to different selective conditions.

Considering that species of the genus Cichla are piscivorous and cause negative impacts on native ichthyofauna, which can lead to the local extinction of its prey (Zaret \& Paine, 1973; Latini \& Petrere, 2004), C. piquiti may cause an ecological and ichthyofaunal disequilibrium in the Itumbiara Reservoir. Thus, experimental fisheries must be implemented to evaluate the fish community of the reservoir, and if necessary, methods of population control must be implemented for this exotic species.

\section{Acknowledgements}

The authors are grateful to the staff of the Furnas Hydrobiology and Hatchery Station, the biologist Leonardo Bornacki Salim for the assistance during the collection of the fishes and the Brasilian Research Foundations: CNPq, FAPEMIG and FIP-PUC Minas for financial support, and also Dr. Erik Wild for suggestions on the English version and to anonymous referees for improving the present study.

\section{Literature Cited}

Bazzoli, N. 2003. Parâmetros reprodutivos de peixes de interesse comercial na região de Pirapora. Pp. 291-306. In: Godinho, H. P. \& A. L. Godinho (Eds.). Águas, peixes e pescadores do São Francisco das Minas Gerais. Belo Horizonte, PUC Minas, 468p.

Bernacsek, G. M. 1984. Guidelines for dam design and operation to optimize fish production in impounded river basins. CIFA Technical Paper, 11: 1-98.

Chellappa, S., M. R. Câmara, N. T. Chellappa, M. Beveridge \& F. A. Huntingford. 2003. Reproductive ecology of a neotropical cichlid fish, Cichla monoculus (Osteichthyes: Cichlidae). Brazilian Journal of Biology, 63(1): 17-26.

Gomiero, L. M. \& F. M. S. Braga. 2003. Relação peso-comprimento e fator de condição para Cichla cf. ocellaris e Cichla monoculus (Perciformes, Cichlidae) no reservatório de Volta Grande, rio Grande - MG/SP. Acta Scientiarum, Biological Sciences, 25(1): 79-86.

Gomiero, L. M. \& F. M. S. Braga. 2004. Reproduction of species of the genus Cichla in a reservoir in southeastern Brazil. Brazilian Journal of Biology, 64(3B): 613-624.

Gomiero, L. M., G. A. Villares Jr. \& F. Naous. 2008. Relação pesocomprimento e fator de condição de Cichla kelberi (Perciformes, Cichlidae) introduzidos em um lago artificial no Sudeste brasileiro. Acta Scientiarum, Biological Sciences, 30(2): 173-178.

Hoeinghaus, D. J., K. O. Winemiller, C. A. Layman, D. A. Arrington, \& D. B. Jepsen. 2006. Effects of seasonality and migratory prey on body condition of Cichla species in a tropical floodplain river. Ecology of Freshwater Fish, 15(4): 398-407.

Jepsen, D. B., K. O. Winemiller \& D. C. Taphorn. 1997. Temporal patterns of resource partitioning among Cichla species in a Venezuelan blackwater river. Journal of Fish Biology, 51: 10851108.

Jepsen, D. B., K. O. Winemiller, D. C. Taphorn \& D. Rodriguez Olarte. 1999. Age structure and growth of peacock cichlids from rivers and reservoirs of Venezuela. Journal of Fish Biology, 55: 433-450.
Kullander, S. O. 2003. Family Cichlidae. Pp. 605-655. In: Reis, R. E., S. O. Kullander \& C. J. Ferraris Jr. (Eds.). Check List of the Freshwater Fishes of South and Central America. Porto Alegre, Edipucrs, 729p.

Kullander, S. O. \& E. J. G. Ferreira. 2006. A review of the South American cichlid genus Cichla, with descriptions of nine new species (Teleostei: Cichlidae). Ichthyological Exploration of Freshwaters, 17(4): 289-398.

Latini, A. O. \& M. Petrere. 2004. Reduction of a native fish fauna by alien species: an example from Brazilian freshwater tropical lakes. Fisheries Management and Ecology, 11(2): 71-79.

Lowe-McConnell, R. H. 1969. The cichlid fishes of Guyana, South America, with notes on their ecology and breeding behaviour. Zoological Journal of the Linnaean Society, 48(2): 255-302.

Lowe-McConnell, R. H. 1979. Ecological aspects of seasonality in fishes of tropical waters. Symposia of the Zoological Society of London, 44: 219-241.

Magalhães, A. L. B., Y. Sato, E. Rizzo, R. M. A. Ferreira \& N. Bazzoli. 1996. Ciclo reprodutivo do tucunaré Cichla ocellaris (Schneider, 1801) na represa de Três Marias, MG. Arquivo Brasileiro de Medicina Veterinária e Zootecnia, 48(1): 85-92.

Muñoz, H., P. A. van Damme \& F. Duponchelle. 2006. Breeding behaviour and distribution of the tucunaré Cichla aff. monoculus in a clear water river of the Bolivian Amazon. Journal of Fish Biology, 69: 1018-1030.

Novaes, J. L. C., E. P. Caramaschi \& K. O. Winemiller. 2004. Feeding of Cichla monoculus Spix, 1829 (Teleostei: Cichlidae) during and after reservoir formation in the Tocantins river, Central Brazil. Acta Limnologica Brasiliensia, 16(1): 41-49.

Santos, G. B. 1999. Estrutura das comunidades de peixes de reservatórios do sudeste do Brasil, localizados nos rios Grande e Paranaíba, bacia do Alto Paraná. Unpublished Ph.D. Dissertation, Universidade Federal de São Carlos, São Carlos, 166p.

Santos, G. B., P. M. Maia-Barbosa, F. Vieira \& C. M. López. 1994. Fish and zooplankton communities structure in reservoirs of southeastern Brazil: Effects of the introduction of exotic predatory fish. Pp. 77-83. In: Pinto-Coelho, R. M., A. Giani \& E. von Sperling (Eds.). Ecology and human impact on lakes and reservoirs in Minas Gerais with special reference to future development and management strategies. Belo Horizonte, Segrac, 193p.

Selman, K. \& R. A. Wallace. 1989. Review cellular aspects of oocyte growth in teleost. Zoological Science, 6: 211-231.

Souza, J. E., E. N. Fragoso-Moura, N. Fenerich-Verani, O. Rocha \& J. R. Verani. 2008. Population structure and reproductive biology of Cichla kelberi (Perciformes, Cichlidae) in Lobo Reservoir, Brazil. Neotropical Ichthyology, 6(2): 201-210.

Vazzoler, A. E. A. M. 1996. Biologia da reprodução de peixes teleósteos: teoria e prática. Maringá, Eduem, 169p.

Winemiller, K. O. 2001. Ecology of peacock cichlids (Cichla spp.) in Venezuela. Journal of Aquariculture and Aquatic Sciences, 9: 93-112.

Winemiller, K. O., D. C. Taphorn \& A. Barbarino-Duque. 1997. Ecology of Cichla (Cichlidae) in two blackwater rivers of Southern Venezuela. Copeia, 1997(4): 690-696.

Zaret, T. M. 1980. Life history and growth relationships of Cichla ocellaris, a predatory South American cichlid. Biotropica, 12(2): 144-157.

Zaret, T. M. \& R. T. Paine. 1973. Species introduction in a tropical lake. Science, 182: 449-455.

Accepted August 12, 2009 Published December 18, 2009 